\title{
ANALISIS RASIO LIKUIDITAS, PROFITABILITAS, SOLVABILITAS DAN PERPUTARAN PERSEDIAAN UNTUK MENILAI KINERJA PERUSAHAAN RETAIL YANG TERDAFTAR DI BEI
}

\author{
Masta Sembiring \\ Dosen Universitas Muhammadiyah Sumatera Utara \\ email:mastasembiring@umsu.ac.id
}

\begin{abstract}
Measurement of a company's performance can be seen from financial ratio or stock returns. This study aims to know whether liquidity, profitability, solvency, and inventory turnover have an effect after being analyzed on the performance of company on companies listed on Indonesia Stock Exchange. The variables used are Current Ratio, Return on Investment, Debt to Asset Ratio, Inventory Turnover to Net Profit Margin. The population in this study consisted of 148 companies in retail trade, service and investment group that were listed on the Indonesia Stock Exchange. The sample chosen by purposive sampling was chosen to be 17 companies listed on Indonesia Stock Exchange during 2014 to 2017. Data collection techniques used were documentation techniques. Data processing technique used is data processing with SPSS version 21. Data analysis method used is multiple linear regression method. Results of the T test show that partially Current Ratio, Debt to Asset Ratio, and inventory turnover have a negative and significant effect on company performance, while Return On Investment has a positive and significant influence on company performance. The results of the $F$ test analysis indicate that the variable Liquidity Ratio, Profitability, Solvability and Inventory Turnover together have a significant effect on company performance.
\end{abstract}

Keywords : Liquidity; Profitability; Solvency; Inventory Turnover; Company Performance.

\section{PENDAHULUAN}

Sering kita ketahui banyak pengusaha yang mendirikan perusahaannya mempunyai tujuan ingin perusahaannya maju dan memaksimumkan kinerja perusahaan serta mendapatkan keuntungan semaksimal mungkin. Kinerja merupakan hasil nyata yang dicapai yang dipergunakan untuk menunjang kegiatan dalam suatu perusahaan. Pengukuran kinerja suatu perusahaan dapat dilihat dari rasio keuangan ataupun return saham. Informasi rasio keuangan bersumber pada laporan keuangan perusahaan yang bersangkutan.

Kinerja keuangan perusahaan merupakan gambaran kondisi keuangan perusahaan pada suatu periode tertentu baik menyangkut aspek penyedia dana maupun penyaluran dana, yang biasanya diukur dengan indikator kecukupan modal, likuiditas, dan profitabilitas. Dalam mengevaluasi sejauh mana kinerja keuangan perusahaan, salah satu indikator yang dipakai oleh perusahaan adalah informasi akuntansi berupa laporan keuangan yang dikeluarkan oleh perusahaan. Menurut (Sugiyono, 2008:58), perputaran persediaan merupakan perputaran atas dana yang terdapat dalam persediaan, yaitu barang atau bahan yang dibeli atau diproduksi oleh perusahaan yang dipergunakan dalam proses produksi atau siap dijual satu periode akutansi. 


\section{TINJAUAN PUSTAKA}

\section{Kinerja Keuangan}

Kinerja keuangan merupakan gambaran dari pencapaian keberhasilan perusahaan dapat diartikan sebagai hasil yang telah dicapai atas berbagai aktivitas yang telah dilakukan. Dapat dijelaskan bahwa kinerja keuangan adalah suatu analisis yang dilakukan untuk melihat sejauh mana suatu perusahaan telah melaksanakan dengan menggunakan aturan-aturan pelaksanaan keuangan. Dalam penelitian ini kinerja perusahaan diukur dengan nilai keuntungan bersih atau Net Profit Margin.

\section{Rasio Likuiditas}

Rasio likuiditas adalah rasio yang menggambar kemampuan perusahaan dalam memenuhi kewajiban (utang) jangka pendek (Kasmir, 2010:129).

\section{Rasio Profitabilitas}

Menurut (Prihadi, 2010:138) profitabilitas adalah kemampuan menghasilkan laba. Pengertian laba biasa bermacam-macam, tergantung dari kebutuhan dari pengukuran laba tersebut.

\section{Rasio Solvabilitas}

Menurut (Subramanyam, 2010:46) solvabilitas menunjukkan kemampuan perusahaan untuk memenuhi kewajiban jangka panjangnya. Rasio ini digunakan untuk mengukur kemampuan perusahaan memenuhi kewajiban-kewajiban jangka panjangnya.

\section{Perputaran Persediaan}

Menurut (Atmaja, 2008:405) Persediaan merupakan salah satu komponen modal kerja yang tingkat likuiditasnya paling rendah dibandingkan dengan komponen modal kerja lainnya. Jumlah dan jenis persediaan sangat tergantung pada besar dan bentuk perusahaan.

\section{Penelitian Terdahulu}

(Maith, 2013) Dalam Penelitiannya yang berjudul “Analisis Laporan Keuangan Dalam Mengukur Kinerja Keuangan Pada PT. Hanjaya Mandala Sampoerna Tbk.” Hasil penelitian menunjukkan berdasarkan rasio likuiditas setiap tahunnya mengalami peningkatan sehingga keadaan perusahaan dikategorikan dalam keadaan baik (liquid). Dari rasio solvabilitas menunjukkan bahwa modal perusahaan tidak lagi mencukupi untuk menjamin hutang yang diberikan oleh kreditor sehingga keadaan perusahaan dikatakan dalam keadaan tidak baik (insolvable). Ditinjau dengan rasio aktivitas menujukkan peningkatan di setiap tahunnya sehingga keadaan perusahaan dikatakan dalam keadaan baik. Berdasarkan rasio profitabilitas menunjukkan adanya peningkatan dari tahun ke tahun sehingga dapat dikatakan keadaan perusahaan berada pada posisi yang baik.

\section{Hipotesis} ini, yaitu :

Berdasarkan Penelitian terdahulu, maka penulis merumuskan hipotesis dalam penelitian

$\mathrm{H}_{1}$ : Rasio Likuiditas berpengaruh setelah dianalisis terhadap kinerja perusahaan retail yang terdaftar di BEI.

$\mathrm{H}_{2}$ : Rasio Profitabilitas berpengaruh setelah dianalisis terhadap kinerja perusahaan retail yang terdaftar di BEI.

$\mathrm{H}_{3}$ : Rasio Solvabilitas berpengaruh setelah dianalisis terhadap kinerja perusahaan retail yang terdaftar di BEI.

$\mathrm{H}_{4}$ : Perputaran Persediaan berpengaruh setelah dianalisis terhadap kinerja perusahaan retail yang terdaftar di BEI.

$\mathrm{H}_{5} \quad$ : Rasio Likuiditas, Profitabilitas, Solvabilitas, dan Perputaran Persediaan berpengaruh setelah dianalisis terhadap kinerja perusahaan retail yang terdaftar di BEI. 


\section{METODE}

\section{Desain Penelitian}

Penelitian ini adalah metode penelitian kuantitatif. Metode penelitian kuantitatif dapat diartikan sebagai metode penelitian yang digunakan untuk meneliti populasi atau sampel tertentu, pengumpulan data menggunakan instrumen penelitian, analisis data bersifat kuantitatif / statistik dengan tujuan untuk menguji hipotesis yang telah ditetapkan.

\section{Populasi dan Sampel}

Populasi dalam penelitian ini adalah seluruh perusahaan Retail Trade, Service and Investment yang terdaftar di Bursa Efek Indonesia selama periode 2014-2017 yang berjumlah 148 perusahaan. Sampel adalah bagian dari jumlah dan karakteristik yang dimiliki oleh populasi tersebut (Sugiyono, 2012:116). Teknik pengambilan sampel pada penelitian ini yaitu dengan menggunakan Purposive Sampling.

\section{Teknik Pengumpulan Data}

Data dalam penelitian ini berdasarkan sumbernya adalah data sekunder yaitu data yang diperoleh atau dikumpulkan oleh pihak lain yang dalam hal ini adalah pusat data referensi pasar modal PT Bursa Efek Indonesia. Data tersebut berupa laporan keuangan, yaitu neraca dan laporan laba rugi selama periode pengamatan tahun 2014 sampai tahun 2017.

\section{Metode Analisis Data}

Analisis data adalah proses mencari dan menyusun secara sistematis data yang diperoleh dari hasil wawancara, catatan lapangan, dan dokumentasi (Sugiyono, 2010:428).

\section{Statistik Deskriptif}

Menurut (Sugiyono, 2012:148), statistik deskriptif adalah statistik yang digunakan untuk menganalisa data dengan cara mendeskripsikan atau menggambarkan data yang telah terkumpul sebagaimana adanya tanpa bermaksud membuat kesimpulan yang berlaku untuk umum atau generalisasi.

\section{Uji Asumsi Klasik}

Uji normalitas bertujuan untuk menguji apakah dalam model regresi, variabel pengganggu atau residual memiliki distribusi normal. Uji normalitas dapat dilakukan dengan menggunakan Histogram Regression Residual yang sudah di standarkan, analisis p-plots dan juga menggunakan Nilai Kolmogorov-Smirnov (Wibowo, 2012).

Uji autokorelasi bertujuan untuk mengetahui apakah dalam regresi terdapat hubungan antara residual atau residual yang bersifat model tidak saling independent. Autokorelasi dapat dideteksi dengan menggunakan salah satu aplikasi yang ada dalam program SPSS versi 21 dengan melakukan pengujian Run Test. Run Test digunakan untuk melihat apakah data residual terjadi secara random atau tidak (sistematis).

Menurut (Ghozali, 2013:105), Uji multikolinearitas bertujuan untuk menguji apakah model regresi ditemukan adanya korelasi antar variabel bebas (independen). Cara yang dapat digunakan untuk mengetahui adanya multikolinieritas adalah dengan cara menggunakan Uji Variance Influence Factor (VIF).

Uji heteroskedastisitas dilakukan untuk mengetahui apakah dalam suatu model regresi terjadi ketidaksamaan varians residual dari satu pengamatan ke pengamatan lain. 
Ada tidaknya heteroskedastisitas dalam model regresi dapat diketahui dalam pola gambar Scatterplot model.

\section{Analisis Regresi Linear Berganda}

(Suliyanto, 2011:54) menyatakan bahwa dalam regresi berganda variabel tergantung dipengaruhi oleh dua atau lebih variabel bebas, di samping juga terdapat pengaruh dari variabel lain yang tidak diteliti (e).

\section{Uji T}

Pengujian ini dilakukan untuk mengetahui apakah secara parsial pengaruh yang diperoleh memang nyata atau secara kebetulan saja.

Uji F

Uji F digunakan untuk menguji kelayakan model dalam penelitian. Uji F pada dasarnya menunjukkan apakah semua variabel independen yang dimasukkan dalam model mempunyai pengaruh bersama-sama terhadap variabel dependen.

\section{Koefisien Determinasi}

Koefisien Determinasi, Perhitungan ini digunakan untuk mengetahui seberapa besar sumbangan variabel bebas secara parsial terhadap variabel terikat, semakin besar r2 maka variabel bebas tersebut mempunyai pengaruh yang semakin dominan.

\section{Lokasi dan Jadwal Penelitian}

Lokasi penelitian ini dilakukan di kantor Bursa efek Indonesia Kota Batam, Jadwal pelaksanaan penelitian dilakukan dalam 6 (enam) tahapan kegiatan dan disesuaikan dalam waktu 14 minggu (kurang lebih 5 bulan).

\section{HASIL DAN PEMBAHASAN}

Penelitian ini bertujuan untuk mengetahui analisis pengaruh rasio likuiditas (Current Ratio), Rasio profitabilitas (ROI), Rasio solvabilitas (DAR) dan perputaran persediaan untuk menilai kinerja keuangan perusahaan. Data yang digunakan dalam penelitian ini adalah data sekunder, objek dalam penelitian ini adalah perusahaan Retail trade, service, and investment yang terdaftar di Bursa Efek Indonesia periode 2014-2017. Sampel yang diperoleh dari Bursa Efek Indonesia adalah sebanyak 17 perusahaan dari 148 perusahaan Retail Trade, Service, and Investment yang terdaftar di BEI. Data diambil dari laporan keuangan selama 4 tahun berturutturut. Berikut data sampel yang digunakan dari keseluruhan jumlah sampel perusahaan Retail Trade, Service, and Investment yang terdaftar di Bursa Efek Indonesia.

\section{Tabel 1. Sampel Penelitian}

\begin{tabular}{lc}
\hline \multicolumn{1}{c}{ Keterangan } & Jumlah \\
\hline Perusahaan Retail yang terdaftar di BEI (2012-2016) & 148 \\
Perusahaan Retail yang tidak memenuhi kriteria & $(131)$ \\
\cline { 2 - 2 } Jumlah perusahaan Retail yang menjadi sampel & 17 \\
\hline
\end{tabular}

Sumber: Data sekunder diolah (2019)

\section{Analisis Deskriptif}

Statistik deskriptif memberikan gambaran tentang objek penelitian yang dijadikan sampel yang dilihat dari Mean, standar deviasi, nilai maksimum dan minimum, varian, dll. Penjelasan data melalui statistik deskriptif diharapkan memberikan gambaran awal tentang masalah yang diteliti.. Berdasarkan hasil pengelolaan data dengan menggunakan SPSS (Statistical Package for Social Science) Versi 21, maka diperoleh hasil berikut 
Tabel 2. Statistik Deskriptif

\begin{tabular}{lrrrrrr}
\hline & N & Minimum & Maximum & Mean & $\begin{array}{c}\text { Std. } \\
\text { Deviation }\end{array}$ & Variance \\
\hline $\begin{array}{l}\text { Current } \\
\text { Ratio }\end{array}$ & 68 & -1.66 & 0,177083 & .6629 & .78944 & .623 \\
ROI & 68 & -4.61 & -.78 & - & & \\
& & & & & & \\
DAR & 68 & -1.71 & -.05 & -.8196 & .41661 & .174 \\
PP & 68 & .08 & 06.27 & 19.048 & .87834 & .771 \\
NPM & 68 & -.97 & 03.02 & 14.041 & 112.979 & 1.276 \\
Valid N & 68 & & & & & \\
(listwise) & 68963 & & \\
\hline
\end{tabular}

\section{Uji Normalitas}

Kolmogorov-Smirnov, uji ini memiliki Kriteria penilaian yaitu jika tingkat signifikan > 0,05 maka data dapat dinyatakan normal. Output dari tabel KolmogorovSmirnov dibawah ini menunjukkan nilai signifikansi (Asymp. Sig. (2-tailed)) adalah 0,736 dan lebih besar dari 0,05, maka dapat disimpulkan bahwa menurut uji ini, data berdistribusi normal.

\begin{tabular}{llr}
\multicolumn{2}{c}{ One-Sample Kolmogorov-Smirnov Test } \\
\hline N & & Unstandardized Residual \\
\hline Normal Parameters & & 68 \\
& & .0000000 \\
& Mean & .52056906 \\
Most Extreme Differences & Std. Deviation & .083 \\
& Absolute & .083 \\
Kolmogorov-Smirnov Z & Positive & -.062 \\
Asymp. Sig. (2-tailed) & & .685 \\
\hline a. Test distribution is Normal. & .736 \\
b. Calculated from data. & &
\end{tabular}

Tabel 3. Kolmogorov-Smirnov

Sumber : Hasil Pengolahan Data SPSS v.21 
Histogram, Kriteria dari analisis ini yaitu data harus mengikuti kurva normal dan berbentuk lonceng.

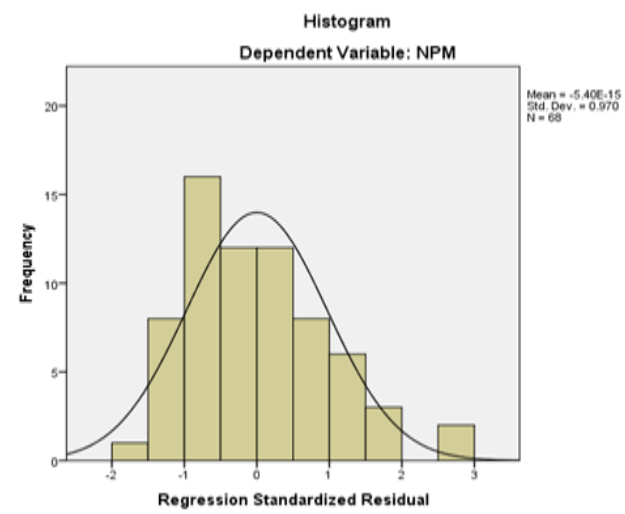

Gambar 1. Histogram

P-Plot, Data dapat dikatakan berdistribusi normal jika titik-titik / plot (sebaran data) mengikuti garis linear.

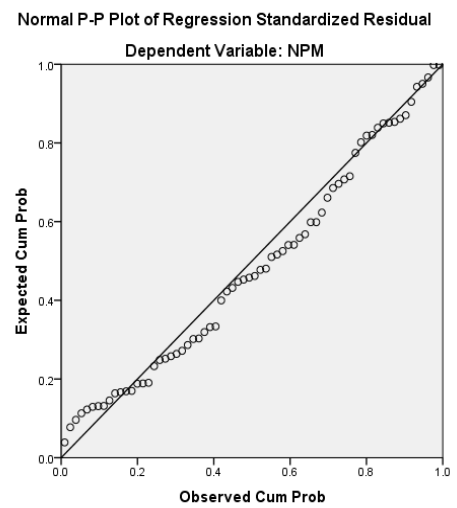

Gambar 2. P-Plot

\section{Uji Autokorelasi}

Output uji autokorelasi yaitu uji Run Test ini dengan nilai tabel pada tingkat signifikansi $5 \%$, jumlah sampel 68 (n).

Dapat dilihat bahwa nilai Asymp. Sig. (2-tailed) adalah 0,051 dan lebih besar dari 0,05, maka dapat dikatakan bahwa data ini bebas dari gejala Autokorelasi.

Tabel 4. Run Test

\section{Runs Test}

\begin{tabular}{lr}
\hline \multicolumn{2}{c}{ Runs Test } \\
\hline Test Value $^{\mathrm{a}}$ & Unstandardized Residual \\
Cases $<$ Test Value & 1.005 .428 \\
Cases $>=$ Test Value & 34 \\
Total Cases & 34 \\
Number of Runs & 68 \\
Z & 13 \\
Asymp. Sig. (2-tailed) & -1.376 \\
\hline
\end{tabular}

a. Median 


\section{Uji Heteroskedastisitas}

Uji heteroskedastisitas dilakukan untuk mengetahui apakah dalam suatu model regresi terjadi ketidaksamaan varians residual dari satu pengamatan ke pengamatan lain. Dalam penelitian ini uji Heteroskedastisitas dilakukan dengan melakukan uji Scatterplot. Berdasarkan hasil dari uji Scatterplot pada gambar disamping tersebut, terlihat tidak terdapat pola tertentu yang jelas, serta titik-titik menyebar diatas dan dibawah angka nol pada sumbu Y maka mengindikasikan tidak terjadi gejala heteroskedastisitas.

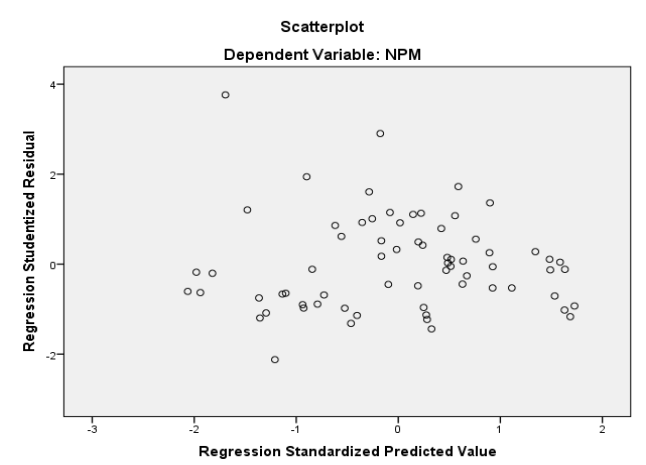

\section{Uji Multikolinieritas}

Berdasarkan Output dari tabel dibawah, nilai Tolerance dari semua variabel independen lebih besar dari 0,10, dan nilai VIF dari semua variabel independen lebih kecil dari 10. Maka dapat dikatakan data ini bebas dari gejala multikoliniearitas.

Tabel 5. Multikolinieritas

\section{Coefficients $^{\mathrm{a}}$}

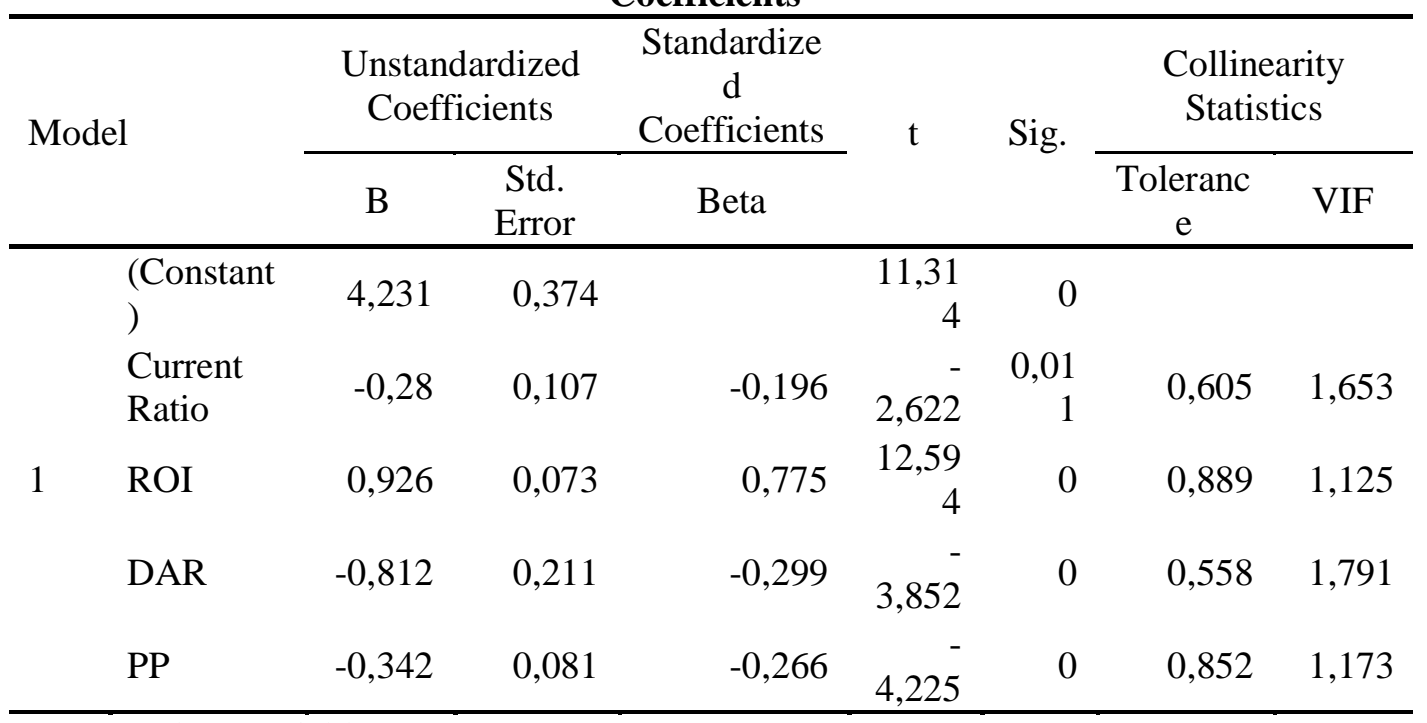

a. Dependent Variable: NPM

\section{Uji Analisis Regresi Linear Berganda}

Dari hasil analisis regresi linear berganda di bawah ini maka dapat dijelaskan beberapa hal antara lain:

1. Nilai konstanta sebesar 4,231. Angka tersebut menunjukkan bahwa jika Current Ratio $\left(X_{1}\right)$, ROI $\left(\mathrm{X}_{2}\right)$, DAR $\left(\mathrm{X}_{3}\right)$, dan Perputaran Persediaan $\left(\mathrm{X}_{4}\right)$ nilainya 0 maka Kinerja Perusahaan (Y) adalah 4,231. 
2. Variabel Current Ratio $\left(\mathrm{X}_{1}\right)$ memiliki nilai koefisien regresi sebesar $-0,280$. Hal ini berarti jika terjadi kenaikan Current Ratio sebesar 1\% maka Kinerja Perusahaan akan mengalami penurunan sebesar 0,280 atau 28\% dengan asumsi variabel independen yang lain dianggap konstan.

3. Variabel ROI $\left(X_{2}\right)$ memiliki nilai koefisien regresi sebesar 0,926 . Hal ini berarti jika terjadi kenaikan ROI sebesar $1 \%$ maka kinerja perusahaan akan mengalami peningkatan sebesar 0,926 atau $92,6 \%$ dengan asumsi variabel independen yang lain dianggap konstan.

4. Variabel DAR $\left(\mathrm{X}_{3}\right)$ memiliki nilai koefisien regresi sebesar -0,812. Hal ini berarti jika terjadi kenaikan DAR sebesar $1 \%$ maka kinerja perusahaan akan mengalami penurunan sebesar 0,812 atau $81,2 \%$ dengan asumsi variabel independen yang lain dianggap konstan.

5. Variabel perputaran persediaan $\left(\mathrm{X}_{4}\right)$ memiliki nilai koefisien regresi sebesar $-0,342$. Hal ini berarti jika terjadi kenaikan komposisi perputaran persediaan sebesar $1 \%$ maka kinerja perusahaan akan mengalami penurunan sebesar 0,342 atau 34,2\% dengan asumsi variabel independen yang lain dianggap konstan.

Tabel 6. Analisis Regresi Linear Berganda

\begin{tabular}{|c|c|c|c|c|c|c|}
\hline \multirow{2}{*}{\multicolumn{2}{|c|}{ Model }} & \multicolumn{2}{|c|}{$\begin{array}{c}\text { Unstandardized } \\
\text { Coefficients }\end{array}$} & \multirow{2}{*}{$\begin{array}{l}\text { Standardized } \\
\text { Coefficients } \\
\text { Beta }\end{array}$} & \multirow[t]{2}{*}{$\mathrm{t}$} & \multirow[t]{2}{*}{ Sig. } \\
\hline & & B & Std. Error & & & \\
\hline \multirow{5}{*}{1} & (Constant) & 4.231 & .374 & & 11.314 & .000 \\
\hline & $\begin{array}{l}\text { Current } \\
\text { Ratio }\end{array}$ & -.280 & .107 & -.196 & -2.622 & .011 \\
\hline & ROI & .926 & .073 & .775 & 12.594 & .000 \\
\hline & DAR & -.812 & .211 & -.299 & -3.852 & .000 \\
\hline & PP & -.342 & .081 & -.266 & -4.225 & .000 \\
\hline
\end{tabular}

a. Dependent Variable: NPM

Sumber : Hasil Pengolahan Data SPSS v.21

Uji T (Parsial)

Tabel 7. Uji T

\begin{tabular}{|c|c|c|c|c|c|c|}
\hline \multirow{2}{*}{\multicolumn{2}{|c|}{ Model }} & \multicolumn{2}{|c|}{$\begin{array}{c}\text { Unstandardized } \\
\text { Coefficients }\end{array}$} & \multirow{2}{*}{$\begin{array}{c}\text { Standardized } \\
\text { Coefficients } \\
\text { Beta }\end{array}$} & \multirow[t]{2}{*}{$\mathrm{t}$} & \multirow[t]{2}{*}{ Sig. } \\
\hline & & $\mathrm{B}$ & Std. Error & & & \\
\hline \multirow{5}{*}{1} & (Constant) & 4.231 & .374 & & 11.314 & .000 \\
\hline & $\begin{array}{l}\text { Current } \\
\text { Ratio }\end{array}$ & -.280 & .107 & -.196 & -2.622 & .011 \\
\hline & ROI & .926 & .073 & .775 & 12.594 & .000 \\
\hline & DAR & -.812 & .211 & -.299 & -3.852 & .000 \\
\hline & PP & -.342 & .081 & -.266 & -4.225 & .000 \\
\hline
\end{tabular}

a. Dependent Variable: NPM

Sumber : Hasil Pengolahan Data SPSS v.21 
dapat dilakukan penjelasan tabel diatas yaitu :

1. Nilai $t_{\text {hitung }}$ untuk variabel Current Ratio $\left(\mathrm{X}_{1}\right)$ yaitu $-2,622$ lebih kecil dibandingkan dengan $\mathrm{t}_{\text {tabel }} 1,999$ dan nilai sig 0,011 lebih kecil dari alpha $(0,05)$, maka secara parsial Current Ratio $\left(\mathrm{X}_{1}\right)$ berpengaruh signifikan terhadap kinerja perusahaan $(\mathrm{Y})$.

2. Nilai $\mathrm{t}_{\text {hitung }}$ untuk variabel $R O I\left(\mathrm{X}_{2}\right)$ yaitu 12,594 lebih besar dibandingkan dengan $\mathrm{t}_{\text {tabel }} 1,999$ dan nilai sig 0,000 lebih kecil dari alpha $(0,05)$, maka secara parsial $R O I\left(\mathrm{X}_{2}\right)$ berpengaruh signifikan terhadap kinerja perusahaan $(\mathrm{Y})$.

3. Nilai $\mathrm{t}_{\text {hitung }}$ untuk variabel $D A R\left(\mathrm{X}_{3}\right)$ yaitu $-3,852$ lebih kecil dibandingkan dengan $\mathrm{t}_{\text {tabel }} 1,999$ atau nilai sig 0,000 lebih kecil dari alpha $(0,05)$, maka secara parsial $D A R\left(\mathrm{X}_{3}\right)$ mempunyai pengaruh signifikan terhadap kinerja perusahaan $(\mathrm{Y})$.

4. Nilai $t_{\text {hitung }}$ untuk variabel perputaran persediaan $\left(\mathrm{X}_{4}\right)$ yaitu $-4,225$ lebih kecil dibandingkan dengan $\mathrm{t}_{\text {tabel }} 1,999$ atau nilai sig 0,000 lebih kecil dari alpha $(0,05)$, maka secara parsial perputaran persediaan $\left(\mathrm{X}_{4}\right)$ mempunyai pengaruh signifikan terhadap kinerja perusahaan $(\mathrm{Y})$.

\section{Uji F (Simultan)}

Tabel 8. Uji F

ANOVA $^{\mathrm{a}}$

\begin{tabular}{rlrrrrr}
\hline \multirow{2}{*}{ Model } & & $\begin{array}{c}\text { Sum of } \\
\text { Squares }\end{array}$ & \multicolumn{1}{c}{ Df } & $\begin{array}{c}\text { Mean } \\
\text { Square }\end{array}$ & F & \multirow{2}{*}{ Sig. } \\
\hline \multirow{2}{*}{1} & Regression & 67.364 & 4 & 16.841 & 58.435 & $.000^{\mathrm{b}}$ \\
& Residual & 18.156 & 63 & .288 & & \\
& Total & 85.520 & 67 & & & \\
\hline
\end{tabular}

a. Dependent Variable: NPM

b. Predictors: (Constant), PP, ROI, Current Ratio, DAR

Berdasarkan hasil tabel diatas dapat diketahui bahwa nilai $\mathrm{F}_{\text {hitung }}$ sebesar 58,435 lebih besar dari $\mathrm{F}_{\text {tabel }}$ sebesar 2,518 dan nilai signifikansi adalah 0,000 lebih kecil dari nilai alpha 0,05, sehingga keputusan yang diambil adalah $\mathrm{H} 0$ ditolak dan $\mathrm{H} 5$ diterima. Dalam hal ini variabel Current Ratio $\left(\mathrm{X}_{1}\right)$, ROI $\left(\mathrm{X}_{2}\right)$, DAR $\left(\mathrm{X}_{3}\right)$, dan Perputaran Persediaan $\left(\mathrm{X}_{4}\right)$ secara simultan berpengaruh signifikan terhadap Kinerja Perusahaan $(N P M)(\mathrm{Y})$.

Koefisien Determinasi $\left(\mathbf{R}^{2}\right)$

Tabel 9. Koefisien Determinasi $\left(\mathrm{R}^{2}\right)$

Model Summary

\begin{tabular}{lrrrr}
\hline Model & $\mathrm{R}$ & R Square & Adjusted R Square & $\begin{array}{c}\text { Std. Error of the } \\
\text { Estimate }\end{array}$ \\
\hline 1 & $.888^{\mathrm{a}}$ & .788 & .774 & .53684 \\
\hline
\end{tabular}

a. Predictors: (Constant), PP, ROI, Current Ratio, DAR

Berdasarkan Output olah data dari tabel diatas, didapatkan dari nilai koefisien determinasi $\mathrm{R}^{2}$ sebesar 0,774. Hal ini berarti bahwa persentase kontribusi variable Current Ratio, ROI, $D A R$, dan Perputaran Persediaan terhadap Kinerja Perusahaan (NPM) sebesar 77,4\%, 
Analisis Rasio Likuiditas (Current Ratio) untuk menilai Kinerja Perusahaan

Berdasarkan hasil uji signifikansi dari koefisien regresi di atas, Current Ratio yang tinggi akan menurunkan kinerja perusahaan yang dalam penelitian ini diteliti berdasarkan Net Profit Margin $(N P M)$. Hal ini disebabkan oleh semakin tingginya kemampuan perusahaan dalam melunasi kewajiban jangka pendeknya, maka semakin sedikit kemungkinan perusahaan tersebut untuk memperoleh laba yang besar dikarenakan aktiva sudah digunakan untuk memutar atau membayar kewajiban jangka pendek perusahaan tersebut, dan juga karena sebagian modal kerja tidak berputar atau mengalami pengangguran, lalu menyebabkan turunnya kinerja keuangan perusahaan tersebut.

\section{Analisis Rasio Profitabilitas (ROI) untuk menilai Kinerja Perusahaan}

semakin tinggi ROI maka akan semakin meningkatkan kinerja perusahaan. Hal ini disebabkan oleh manajemen masing-masing perusahaan pandai dan bagus dalam mengelola investasinya, dan dari investasi itu dapat meningkatkan laba dan profit dari perusahaan tersebut. ROI juga sebagai bentuk teknik analisa rasio profitabilitas sangat penting dalam suatu perusahaan karena dengan mengetahui $R O I$ dapat akan diketahui seberapa efisien perusahaan guna memanfaatkan aktiva untuk kegiatan operasional dan dapat memberikan informasi ukuran profitabilitas perusahaan.

\section{Analisis Rasio Solvabilitas (DAR) untuk menilai Kinerja Perusahaan}

$D A R$ yang tinggi akan menurunkan kinerja perusahaan. Hal ini disebabkan oleh semakin tingginya tingkat perputaran utang maka akan semakin rendahnya tingkat profit atau keuntungan yang akan dihasilkan oleh perusahaan. Untuk hal ini perusahaan berada pada posisi insolvable yaitu keadaan dimana kemampuan perusahaan untuk membayar hutang-hutangnya secara tepat waktu berada dalam posisi bermasalah bahkan cenderung tidak tepat waktu.

\section{Analisis Perputaran Persediaan untuk menilai Kinerja Perusahaan}

perputaran persediaan yang tinggi akan menurunkan kinerja perusahaan. Hal ini diakibatkan masalah penentuan besarnya investasi atau alokasi modal dalam persediaan mempunyai efek yang langsung terhadap kinerja keuntungan perusahaan. Kesalahan dalam penetapan besarnya investasi dalam inventori akan menekan keuntungan perusahaan.

\section{Analisis Rasio Likuiditas, Profitabilitas, Solvabilitas dan perputaran persediaan untuk menilai Kinerja Perusahaan}

bahwa beberapa variabel memiliki pengaruh negatif terhadap Kinerja Perusahaan dan beberapa variabel lain memiliki pengaruh positif, hal ini menunjukkan realisasi dan fakta yang terjadi di perusahaan-perusahaan yang sudah Go-Public bahwa tidak selalu rasio yang tinggi dapat memberikan keuntungan yang tinggi juga. Rasio-rasio yang telah dibahas diatas juga sangat mempengaruhi laba bersih perusahaan.

\section{SIMPULAN}

Kesimpulan yang dapat diambil dari penelitian ini adalah:

1. Current Ratio mempunyai pengaruh negatif terhadap kinerja perusahaan.

2. ROI mempunyai pengaruh positif terhadap kinerja perusahaan.

3. DAR berpengaruh negatif terhadap Kinerja Perusahaan.

4. Perputaran Persediaan berpengaruh negatif terhadap Kinerja Perusahaan.

5. Current Ratio, ROI, DAR dan Perputaran Persediaan secara simultan berpengaruh terhadap Kinerja Perusahaan. 


\section{SARAN}

Saran yang dapat diambil dari penelitian ini adalah:

1. Pada penelitian ini hanya membahas beberapa variabel dari rasio keuangan, diharapkan peneliti dan pembaca yang berniat untuk meneliti tentang penelitian ini lebih lanjut dapat menambahkan variabel lain yang dapat mempengaruhi kinerja perusahaan.

2. Pada penelitian ini hanya membahas perusahaan pada sektor Trade, Service, and Investment yang terdaftar di BEI. Untuk penelitan selanjutnya diharapkan dapat memperluas sampel penelitian dengan menambah tahun penelitian maupun melakukan penelitian di sektor lain yang terdaftar di BEI.

\section{DAFTAR PUSTAKA}

Atmaja, L. S. (2008). Teori dan Praktek Manajemen Keuangan. Yogyakarta: Penerbit Andi.

Ghozali, I. (2013). Aplikasi Analisis Multivariate Dengan Program IBM SPSS 21 (7th ed.). Semarang: Badan Penerbit Universitas Dipoegoro.

Kasmir. (2010). Analisis Laporan Keuangan. Jakarta: PT.Raja Grafindo Persada.

Maith, H. A. (2013). Analisis Laporan Keuangan Dalam Mengukur Kinerja Keuangan Pada Pt. Hanjaya Mandala Sampoerna Tbk. Jurnal EMBA (Vol. 6191). https://doi.org/10.1145/1863495.1863501

Subramanyam, K. R. (2010). Analisis Laporan Keuangan (10th ed.). Jakarta: Salemba Empat. Sugiyono. (2008). Metode Penelitian Kuantitatif Kualitatif dan R\&D. Bandung: Alfabeta.

Sugiyono. (2010). Metode Penelitian Pendidikan Pendekatan Kuantitatif, kualitatif, dan R\&D. Bandung: Alfabeta.

Sugiyono. (2012). Metode Penelitian Kuantitatif Kualitatif dan R\&D. Bandung: Alfabeta.

Suliyanto. (2011). Ekonometrika Terapan: Teori dan Aplikasi dengan SPSS. Yogyakarta: Penerbit Andi.

Toto, P. (2010). Analisis Laporan Keuangan. Jakarta: PPM Managemen.

Wibowo, A. E. (2012). Aplikasi Praktis SPSS dalam Penelitian. (A. Djojo, Ed.). Yogyakarta: Gava Media. 